\title{
The significance of a 'correct and uniform system of accounts' to the administration of the Poor Law Amendment Act, 1834
}

Article

Accepted Version

Care, V. (2011) The significance of a 'correct and uniform system of accounts' to the administration of the Poor Law Amendment Act, 1834. Accounting History Review, 21 (2). pp. 121-142. ISSN 2155-2851 doi:

https://doi.org/10.1080/21552851.2011.581837 Available at https://centaur.reading.ac.uk/23962/

It is advisable to refer to the publisher's version if you intend to cite from the work. See Guidance on citing.

To link to this article DOI: http://dx.doi.org/10.1080/21552851.2011.581837

Publisher: Taylor \& Francis

All outputs in CentAUR are protected by Intellectual Property Rights law, including copyright law. Copyright and IPR is retained by the creators or other copyright holders. Terms and conditions for use of this material are defined in the End User Agreement.

www.reading.ac.uk/centaur 
Central Archive at the University of Reading

Reading's research outputs online 


\section{The significance of a "correct and uniform system of accounts" to the administration of the Poor Law Amendment Act, 1834}

Verna Care

School of Management, Henley Business School, University of Reading, PO Box 218, Whiteknights, Reading, RG6 6UD, UK

Email: v.care@henley.reading.ac.uk 


\begin{abstract}
Accounting under the new Poor Law represents a significant landmark in the history of government accounting that has hitherto attracted little attention or comment. Charge and discharge accounting is rooted in feudal relationships and persisted well into the nineteenth century in the parishes and municipal corporations of England and Wales, especially in rural areas. In contrast, double-entry bookkeeping (DEB) in central government accounting, became a signature of the modern bureaucratic organisation. This paper argues that these radical differences were nowhere more apparent than in the new administrative apparatus created by the 1834 Poor Law Amendment Act. Evidence is drawn from national and local archives to document the design of an elaborate accounting system through which the central agency of the Poor Law Commission operated. It was not only the design of the accounting system that was important significant but also its implementation. The paper draws on archival material to demonstrate the role of change agents and mimetic processes in institutionalising the new accounting practice. It reveals that in the unions studied there was an impressive uniformity and conformity of local practice in deference to the statutory authority of the Poor Law Commission.
\end{abstract}

Keywords: double-entry bookkeeping; bureaucracy; government accounting; Poor Law; change agents. 


\section{Introduction}

The state has long been an important focus of accounting history research (Colquhoun 2009). In the British context particular attention has recently been devoted to the accounting regimes instituted as part of state systems to relieve poverty. The current paper seeks to contribute to this literature by examining the accounting system introduced in England and Wales under the 1834 Poor Law Amendment Act (hereafter, the new Poor Law). The study differs from earlier explorations of poor law accounting. Gallhofer and Haslam (1994a, 1994b) addressed the considerable influence of Bentham in the discourses around record keeping and accounting and the power of accounting to make the managed - whether paupers or prisoners - visible to the manager. More recently, Walker's $(2004,2008)$ work was concerned with the social implications of Poor Law accounting and its role in constituting social identities. His research has shown how some parishes by the 1830 s classified their expenditure on poor relief using morally judgemental taxonomies of the poor and how the new Poor Law institutionalised a classification of paupers as part of its recording system. By so doing, "the state removed the capacity of the pauper to control the visibility of the stigma of poverty" (Walker 2008, 482). This paper examines other dimensions of poor law accounting by focusing on the significance of financial reporting and bookkeeping in furthering the project for an efficient, centralised and bureaucratic administration of poor relief in the 1830s. It also departs from earlier studies by investigating the implementation of the accounting system introduced under the 1834 Act.

The new Poor Law replaced a parish based system for the administration of poor relief with a more centralised and centrally directed administration. It is cited as the classic example of a parliamentary reform which "imposed new agencies at both central and local level" (Eastwood 1997, 160). A central Poor Law Commission was established and the role of the individual parish was marginalised by the creation of the new Poor Law Unions of parishes. The administrative machinery introduced by the new Poor Law can be seen as an early example of Weber's rational bureaucratic organisation. Salaried officers replaced a voluntary service and personal accountability was displaced by rules, procedures and the requirement to systematically record and report data through an extensive array of forms. 
The concern of Parliament with the increasing and seemingly uncontrolled cost of poor relief was a major factor in poor law reform so it is not surprising that the new Poor Law system of book-keeping and financial reporting received special attention. By 1836, the Poor Law Commission required clerks in all Unions to keep a ledger by means of double-entry and to produce an audited balance sheet at the end of each financial quarter for inspection by local ratepayers. In the context of developments in contemporary government accounting, this was the fullest and most extensive expression of modern accounting and marked a fundamental break with the charge and discharge accounting practice of the past.

Jones (2010) has reviewed the introduction and the role of charge and discharge accounting in the emergence of the administrative state in the Early Middle Ages, demonstrating that this form of accounting was a significant means by which the feudal state was supported and enhanced. Charge/discharge accounting remained the dominant form of accounting at municipal government level well into the nineteenth century. However, the early nineteenth century witnessed conscious efforts to displace the feudal form of accounting with "mercantile" double-entry book-keeping (DEB) in central government (Edwards and Greener 2003) and in the municipal corporations (Coombs and Edwards 1994). This paper adds to our understanding of the history of government administration and accounting change by describing in some detail, the modern, bureaucratic accounting system introduced by the new Poor Law. A study of the archives demonstrates that the design of the new system required significant adjustments and changes in the early years, in many ways attesting to the ground-breaking nature of the change.

The Poor Law Commission presumed that it was "unnecessary to enlarge upon the advantage which the Parish, the Union and the Public will derive from the establishment of a correct and uniform system of accounts" (1835). Having designed the new system, the other, greater challenge, was implementing and institutionalising it. This study reveals the importance of change agents and imitation to the implementation of the new Poor Law accounting system. Change agents included individuals like Chadwick, the Assistant Poor Law Commissioners and those publications of the Poor Law Commission which were intended to show the Union clerks how to record transactions in the ledger. The new accounting practices were initiated and embedded in the localities through the act of copying these examples and model accounts. The archival sources used for the study provide evidence of 
the role of these change agents and the process of imitation. An unexpected finding from the archives was evidence that local officials were not prepared to comply with the new book-keeping rules unless they had a copy of the Order from Parliament requiring them to do so. It would appear that, from the outset, these early institutions of the modern bureaucratic state recognised an essentially bureaucratic form of coercion - the written rules contained in the Order - as sanctioned by the highest authority of law making in the country.

The paper is organised in four main sections. The first section reviews the literature on accounting reform in the early nineteenth century and the second section summarises the state of old Poor Law accounting by the 1830s. Those contemporary debates and accounting practices provide a context for considering the new Poor Law accounting. The third section considers the detail of the "correct and uniform system of accounts" which followed the 1834 legislation, describing how the design of the system changed as inconsistencies and a lack of expertise were exposed. The fourth section analyses evidence concerning the implementation of the new system and discusses the role of change agents and imitation in institutionalising the new accounting prescriptions.

\section{Accounting reform in the early nineteenth century}

The radical reform of the Poor Laws in England and Wales in 1834 created new administrative arrangements which exhibited characteristics of an emerging modern bureaucracy. A key element of the reforms was a standardised system of recording and accounting. This section reviews the debates and developments in government accounting practice as a backdrop to the design of the new Poor Law accounting system. In particular, it identifies antecedents for the adoption of accruals-based double entry bookkeeping (DEB) to underpin financial reporting using a balance sheet, in preference to charge and discharge accounting.

Many researchers have concluded that DEB and charge and discharge accounting are not always mutually exclusive. Logically, this is not surprising as DEB is fundamentally a recording system whereas charge and discharge accounting is a financial reporting system (Napier 1998). At its simplest, DEB is synonymous with systematic bookkeeping in which every debit entry has a corresponding credit entry recorded simultaneously in a set of accounts ${ }^{1}$. There is good evidence to show that it is quite possible to keep 
a record of rents owing (Napier 1991) or of the accrued income and expenditure of municipal corporations (Coombs and Edwards 1994) without DEB. For Bryer, the need of emerging capitalism to calculate the rate of return on invested capital provided the key stimulus for full accruals-based DEB in commercial organisations (Bryer 2000a, 2000b) and, "while DEB is not necessary for calculating the rate of return on capital, it is the only system of bookkeeping in which this objective is enshrined in the method itself" (Bryer 1999, 315). Keenan argued that DEB proved superior to single-entry in large-scale business organisations during and after the Industrial Revolution in England and that the financial reports DEB supported provided better and more complete information suited to the complex agency relationships of the joint stock company (Keenan 1998a, 1998b). ${ }^{2}$ In contrast, Yamey (2005) sees the financial statements in commercial organisations as by-products of the DEB system and, therefore, of little explanatory significance in the adoption of DEB. For him, the "instrumental efficiency" of DEB in coping with large volumes of transactions was of far greater significance.

In government organisations, accruals-based DEB is rarely encountered before the nineteenth century. The exceptions are accounts for the trading activities of municipalities (Coombs and Edwards 1994; Livock 1984). Cash-based DEB was used by the Treasury in France between 1716 and 1726 to control the activities of thousands of individuals who collected taxes and incurred expenditure on behalf of the King where it was seen as a way of standardising recording and facilitating control from the centre (Lemarchand 1999). As the British Parliament's powers to tax and spend increased from the late eighteenth and early nineteenth century, so too did concern to develop more rational and economically efficient government, often including debates about DEB (Edwards et al. 2002; Edwards and Greener 2003; Gallhofer and Haslam 1994a, 1994b). In 1828, the Finance Committee set up a Commission to investigate the "wasteful system of public accounts" and to make specific recommendations on whether or not and to what extent DEB might be introduced in government accounting (Edwards et al. 2002). To the reformers, the commercial model of accounting had an ideological as well as a functional persuasiveness which reflected the political aspirations of the capitalist class newly in the political ascendancy. From this privileged position, DEB and mercantile DEB in particular, symbolised modern, systematic and proper accounting. The Commissioners disagreed as to the form of DEB with the majority advocating a cash-based DEB system without the production of an end of 
period balance sheet. This meant that accounts would remain open until a full cash settlement had been achieved. As a basis for financial reporting, the cash-based DEB systems required the addition of explanatory, narrative entries more attuned to the desire to hold public officeholders personally accountable. This suggests that the influence of the "old society" dominated by the landed aristocracy continued to influence government administration (Edwards et al. 2002; Edwards and Greener 2003). Thus, the debates about the preferred form of bookkeeping encoded broader struggles between contesting sources of power and authority and their associated ideological supports. The majority position in favour of cash-based DEB was a compromise which retained vestiges of feudal, stewardship accounting but, the territory of the debate itself was defined in terms of modern, capitalist models of DEB.

The campaign for accruals-based DEB in central government revived a few years later with the creation of a new Commission by the Whig government (Edwards and Greener 2003). John Bowring was appointed as its Secretary and produced two reports on the Public Accounts in France to demonstrate how the various reforms since the start of the century had radically improved government finances there (Bowring 1831). Over the first quarter of the nineteenth century, government orders were introduced to require the remittance of tax income to the Treasury as quickly as possible and to ensure that there was proper authorization for all expenditure. Bowring emphasized how the recording and reporting system generated regular and standardised information flows which, together with the accruals-based DEB and financial reporting system at the centre, permitted central control of the public finances:

The centralization of all the Public Accounts of France under one Department, that of the Ministry of Finance, is perhaps the best evidence that every difficulty has been really subdued, and the great object of uniformity accomplished. ... Before (the Minister) every fact is laid bare, and he can trace from his position all the radii of that circle of financial administration of which he is the centre

(Bowring 1831, Second Report, 19).

Bowring included a copy of the "Balance of the Administration of the Finances" showing the opening balances at the start of the year, receipts and payments during the year and the closing balances on the treasury, tax and 
expenditure accounts to illustrate his claims. Bowring has been described as "an uncritical admirer" of DEB and exercised considerable influence on government accounting (Parker 1993). The 1831 Commission advised the use of DEB and the production of a balance sheet at the year-end in all British Government departments, citing the practices of business as well as the French example to give credibility and weight to their case (Edwards and Greener 2003). However, the call appeared to have been largely ignored as Bowring's survey of practice in government departments in 1844 showed a preference for cash-based DEB (ibid).

Parliament's appetite for reform was expressed further by the formation of a government commission to report upon corrupt practices in municipal administration and resulted in the 1835 Municipal Corporations Act. However, this Act did not prescribe DEB or indeed any specific form of bookkeeping or financial reporting, requiring simply that accounts should be prepared, published and audited (Coombs and Edwards 1994). The commission established in 1832 to investigate the administration of the poor law had a very different result. The new Poor Law established a central body to which new local administrative organisations reported. Within two years, the central body had designed an accruals-based DEB and financial reporting system for use in the new Unions. Different strategies were adopted in these two arenas of local government although both were intended to improve the efficiency of local administration and counter corruption. A key factor explaining this may be the strength of local government organisations relative to central government. In the case of the municipalities, the nineteenth century was a period of rapid growth in wealth and political power for many. This would have made them far less amenable to direct central control whereas, the Poor Law reform provided an opportunity for radical new experimentation in modern bureaucratic government. ${ }^{3}$ Individual rural parishes were a much weaker target for reform.

Two consistent themes emerge in the early nineteenth century reports advocating accounting reform. First, there is the desire to impose uniformity in place of disorder and, second to build knowledge of the public finances on the basis of correct records in place of uncertainty over levels of public spending. Modernisers, like Bowring, stressed the need for centralizing powers to determine how these aims could be achieved. Accruals-based DEB was promoted to deliver uniformity, correctness and order with the production of income and expenditure accounts and year-end balance sheets

Page 6 
permitting an arithmetic check on the bookkeeping system and a means of reporting the financial position of the government department at the end of each financial year. Moreover, accruals-based DEB had a symbolic legitimacy for modernisers in transferring notions of efficient, business-like approaches to government. ${ }^{4}$ Thus, it is argued here that the DEB system and the periodic closing of accounts to the balance sheet had a defining and a constituting role in the history of the modern, bureaucratic form of government organisation. Max Weber contended that the "decisive reason for the advance of bureaucratic organization has always been its purely technical superiority over any other form of organization" (Weber 1991, 214). The mechanisms by which bureaucracy functions are summarised as administration "without regard for persons" and according to "calculable rules". DEB and the financial reporting based upon it exemplified a technology of bureaucracy. Weber discussed the differences between feudal authority (or domination) and rational, bureaucratic forms; the former using formally unremunerated honorific service where the social and economic status of individuals determined the discharge of administrative functions and the latter, with salaried officers, trained as experts in specialised areas of administration. In the former, arbitrary and personal decision-making were the norm whereas, in a bureaucratic administration, there is "equality before the law" or a set of abstract, impersonal rules. Just as charge and discharge accounting was a form of financial reporting which aptly expressed the feudal relationships of personal obligation and stewardship (Jones 2008), so, accruals-based DEB, income and expenditure accounts and balance sheet reporting emerged as synonymous with efficiency whether in private enterprise or government organisations. However, as Weber was keen to stress, feudal and other forms of authority could survive as administrative structures, intersecting with bureaucratic organisational forms. At the descriptive level, this is exactly what we see with the reporting and accounting requirements of the new Poor Law. The changes in government accounting practices and the debates taking place a few years earlier affected the new Poor Law accounting system designed in 1835 and revised in 1836. The next two sections explain the rationale for reform, the survival of feudal modes of accounting and the introduction of modern bureaucratic modes of accounting.

\section{Accounting under the old Poor Law}

Under the 1601 Poor Law Act (the $43^{\text {rd }}$ Elizabeth), the parish was responsible for the relief of poverty amongst its own residents. Justices of 
the Peace were empowered to nominate the churchwardens and overseers, authorise the rate and adjudicate appeals made by ratepayers (Coombs and Edwards 1990). The law "placed squarely on the shoulders of JPs the ultimate responsibility for raising and spending local monies" (ibid. 155). Churchwardens and overseers were appointed annually from amongst the parish ratepayers, as unpaid officers. The overseers were responsible for the collection of the poor rate (the charge in their account) and payments made in the discharge of their duty to relieve the poor (the discharge in their account). Once a year, they gave their account to magistrates and the parish ratepayers and handed over any money still held. This was a world where single entry accounting was the norm and in which "charge/discharge accounting was determined by its originally feudal context but ... persisted down the years and pervaded the economy as a written manifestation of the "obligation to serve" imposed by governments of the locality on inhabitants" (Jones 1985, 208). The Poor Law was amended many times over the following two hundred years. Coombs and Edwards (1990) chart the calls on parish officers to produce written and more accurate accounts, and the increased and more explicit powers conferred on JPs to inspect, audit and sanction those accounts. These measures generally failed to impose greater efficiency and accountability in Poor Law administration, and accounting practices "were invariably considered appalling in small rural parishes" (Walker 2004, 98).

By 1831-2 the poor rates for England and Wales had risen by over $60 \%$ in thirty years to $£ 8.6$ millions (Digby 1982). Social unrest by unemployed agricultural labourers forced to claim financial support and protests from ratepayers at the increasing cost precipitated the establishment of a Royal Commission in 1832 "for Inquiring into the Administration and Practical Operation of the Poor Laws" (Brundage 1988). It was chaired by Nassau Senior, a professor of the new discipline of political economy at Oxford and a Benthamite. The most notable of the assistant commissioners appointed to travel the country gathering evidence for the Commission was Edwin Chadwick, a 'Benthamite from finger to toe' (Englander 1998, 9). On the strength of his report on the operation of the Poor Laws in East London and Berkshire, Chadwick was made a full Commissioner and, with Senior, was responsible for writing the final Report presented to Parliament in 1834. Chadwick is credited with writing the Report's recommendations section (Finer 1970) although Senior may have substantially rewritten it (Webb and Webb 1952). 
The parish system was heavily condemned in the Royal Commission's Report as inefficient, corrupt and inadequate. However, while the overwhelming picture is of badly kept, confused, partial, incomprehensible or non-existent records, Walker notes occasional reference to more systematic records and the use of accounting systems based on printed forms. "These examples confirmed to the Royal Commissioners that systematic accounting could be achieved and the benefits that resulted from it" $(2004,100)$. At the time, those benefits were invariably presented in economic terms; that is, reduction of the cost of poor relief, greater efficiency in the use of rate revenues and the prevention of fraud.

The 1834 Act replaced the old parish system by making provision for the grouping of parishes into Unions run by a Board of Guardians made up of elected ratepayers from the constituent parishes and local magistrates as exofficio members. It was the responsibility of the Board to administer poor relief in the area of the Union. New appointments of salaried officials formed the Union executive. As a result of the changed administration, the responsibilities and functions of individual parishes were dramatically reduced. To counter localism and enforce a common and uniform system of administration across England and Wales, the Act also established a new central agency, the Poor Law Commission, which had wide-ranging powers to direct the Unions. Many years later, in a letter to Earl Russell, Chadwick claimed to have been the architect of this administrative structure which he described as a "combination of the principles of central control with local action" (Brundage 1988, 30). ${ }^{5}$

The administrative machinery created by the 1834 Poor Law Amendment Act marked a significant historical juncture in the formation of the modern, bureaucratic state. However, even the Poor Law Commission itself, the apex of the new administrative machinery, fused elements of the feudal and the rational. The three Commissioners were salaried officers - an essential characteristic of Weber's bureaucratic form of organisation - yet their appointment demonstrated that "aristocratic "jobbery" had triumphed over considerations of merit" (Brundage 1988, 40). ${ }^{6}$ Chadwick had to be content with the position of Secretary to the Commission on a much lower salary. Also, while the Poor Law Commission was a centralising authority, the Unions were not - as Chadwick may have wished - merely executive organisations in the localities. Each Union was a unit of local government as well as administration. The Boards of Guardians were formed on the one hand from elected representatives - thereby recognising a democratic voice 
in local government - and on the other, included ex-officio members drawn from the local landed gentry. The extent to which this represented a continuity of the old social and political relationships in rural localities or a defeat of the power of the landed gentry has been much debated by historians. Some argue that the gentry had become feudal relics marginalized by the changed political and economic environment of the 1830 's. The authority of the magistrates exercised through highly localized, personal patronage and favour, was by-passed by the new legislation (Dunkley 1981). According to Eastwood, the majority of the gentry acquiesced in the new administration; they did not welcome the reforms or embrace "the sinister and ultimately subversive principles of utilitarian centralism and classical political economy" (1990, 193). Other historians identify a modernizing trend amongst significant sections of the gentry who had become capitalist farmers. They argue that these rural elites maintained their local positions of power by adapting to the new regime (Brundage 1990) and even, in some instances, played a leading role in the administrative changes (Mandler 1990).

\section{The design of an accounting system for a new era in public administration}

While the new Poor Law did not mark a complete political break with the past the same cannot be said about the accounting system it introduced. The bookkeeping rules formed part of the administrative system of the new regime. Here there was scope for establishing a clear marker of the aspiration for a modern, bureaucratic organizational form. These rules were designed by the central Poor Law Commission who expected compliance by local office holders.

\section{The 1835 Order}

In September 1835, the Poor Law Commissioners issued an "Order for the Keeping, Examining, and Auditing of the Accounts of the (named) Union and of the several Parishes of which it is composed" (Poor Law Commissioners 1835). Chadwick authored the Order and the accompanying "explanatory statement" which begins by stating that the Poor Law Commissioners:

...deem it unnecessary to enlarge upon the advantage which the 
Parishes, the Union, and the Public, will derive from the establishment of a correct and uniform system of Accounts; and they feel confident that, to secure this advantage, you will use your utmost endeavours to overcome the difficulties which the introduction of such a system may present

(Poor Law Commissioners 1835, 90).

The first part of this statement underlined the concern that accounting should be standardised. The second part of the statement implicitly acknowledged that for many in the localities, the new Order would be seen as a different way of doing things. The changes related to the new division of responsibilities for the administration of poor relief. At each administrative level, officers were required to complete specially designed and printed forms. These forms, together with the instructions on how to complete them were intended to ensure uniformity and standardisation of record keeping and accounting throughout England and Wales as the new Unions were established. The Order divided the Forms of Account into four classes, ordered in Schedules as follows:

Schedule A Parish Accounts kept by Churchwardens and Overseers of the parishes which constituted the Union

Schedule B Union Accounts kept by the Clerk to the Board of Guardians Schedule C Workhouse Accounts kept by the Master of the Workhouse Schedule D Out-Door Relief Accounts kept by the Relieving Officers of the Union.

The Schedule C and Schedule D forms are concerned with the accurate recording of details pertaining to those given relief. These records had a constitutive role in the stigmatising of the poor (Walker 2008) but in bookkeeping terms, they included important subsidiary records supporting the Union Accounts (Schedule B).

The 1834 Act removed the responsibilities of the parish overseers and churchwardens for the disbursement of relief to the poor. Their financial function, once their parish became part of a Union, was to collect the poor rates and remit the money to the Union treasurer. The Schedule A Forms of Account prescribe a single-entry cash recording system but with notes or memoranda for debtors (ratepayers) and creditors (the Union). They appear to be an attempt to adapt what may have been "best practice" in rate collection in some parishes before the 1834 Act rather than introduce any

Page | 11 
radically new bookkeeping and accounting practices. The parish officers continued as unsalaried volunteers and, as before, the "charge" on individual parish officers was to collect the rate income but after the formation of a Union, their "discharge" was simply the remittance of those sums to the Union treasurer. The 1835 Order imposed a new hierarchy of bureaucratic authority over the record keeping of the parish officers by requiring the completion of specially designed forms. However, no attempt was made to move to DEB in these accounts. ${ }^{7}$

The underlying presumption of the new Poor Law was that each parish was responsible for supporting its own paupers but the system of relief was administered entirely by the Union through a small number of salaried Relieving Officers (Out-Maintenance) and in the single, general Union Workhouse (In-Maintenance). While the parishes had a long history, the Poor Law Unions were radically new organisations in local government. ${ }^{8}$ Their powers and responsibilities were without precedent Considering also, that the charge of inefficiency and lack of economy levelled at the parishes was one of the strongest arguments in favour of the 1834 Act, the Poor Law Commission was under pressure to ensure that the Unions were administratively beyond reproach. Chadwick saw a "correct and uniform accounting system" as an essential mechanism for achieving administrative order, efficiency and probity, especially in the Unions. The instructions to the Clerk to the Board of Guardians form the most substantial part of Chadwick's Explanatory Statement. He begins as follows:

The Accounts to be kept by this Officer, are the General Accounts of the Union. The Cash Accounts, which are the most complex and important, are to be contained in the Minute book and the Ledger; and with a view to illustrate the directions here given, and to furnish a detailed example of the mode in which these books are required to be kept, a specimen of the Cash Accounts of a small Union of ten Parishes is hereto subjoined (Poor Law Commission 1835, 91).

The minute book provided the detailed explanatory narrative, serving as a journal from which entries were posted into the ledger accounts. The Ledger was to be divided into a number of titles or heads of account as follows:

1. Parochial Account of Contribution and Appropriation;

2. Treasurer of the Union (the bank account); 

3. In-Maintenance Charges;
4. Out-Relief Charges;
5. Establishment Charges and
6. Labour Account (for task work undertaken in the Workhouse).

The Explanatory Statement relates that these heads of account in the ledger had been selected "with the intention of cross or doubly entering under these heads all its receipts and payments". The Ledger does not include personal accounts for the Relieving Officers, the salaried officers of the Union or the tradesmen supplying the workhouse for example. The Explanatory Statement permitted the clerk to keep such "private accounts" but states that they are not necessary. If these accounts were opened they were required be kept by double entry with the appropriate expense account (In-Maintenance, Out-Maintenance or Establishment).

On completing the Ledger Accounts, the Clerk was required to produce a quarterly abstract of the Union Accounts which combined on a parish by parish basis, statistics of paupers relieved with the receipts and expenditure of the Union (Schedule B, Form 11). This, together with supporting documents, records and vouchers, was to be made available for inspection by the ratepayers of the Union prior to auditing. On the basis of this and records of other parish receipts and expenditure, the Clerk completed another quarterly abstract of parish accounts (Form 14). The 1835 Order stated that Form 14 should be sent to the Commission and a copy retained by the Board of Governors. This was the source document used by the Commission to compile statistics on the costs of poor relief in England and Wales by combining data from all the Unions. The production of printed forms and the Order for their completion was designed to ensure that comparable data were collected from across England and Wales. The initial intention was to demonstrate the reduction in costs as a benefit of the improved administration. ${ }^{9}$

The specimen accounts used to demonstrate the bookkeeping required are a surprising muddle. Each parish is listed in the Parochial Account in the Union's Ledger and the amount of rates required from each is noted on the debit side. When the Parish officers remitted the cash to the Union Treasurer, the date of receipt is entered against the entry already made in the Parochial Account while a further debit entry for the receipt of cash is made in the Treasurer's Account. Throughout the quarter, debit entries are made in the In-Maintenance Charges, Out-Relief Charges and Establishment 
Charges Accounts of expenses incurred based on invoices from suppliers and entries in the Relieving Officers' books. There are no corresponding credit entries for these postings. Periodically, suppliers and salaried officers were paid and Relieving Officers advanced or reimbursed for the cash relief they had paid out. When cash payments are made, the In-Maintenance Charges, Out-Relief Charges and/or Establishment Charges Accounts are credited and the Treasurer's Account is credited with the amounts, also. That is, the specimen accounts show two credit entries in two ledger accounts for the same transaction.

At the end of the quarter, the total of expenses incurred (debited) in the InMaintenance Charges, Out-Relief Charges and Establishment Charges Accounts are totalled and exactly matched by the total credit entries for cash disbursed in respect of these expenses. This in turn equals the cash disbursements on the credit side of the Treasurers Account. The costs of InMaintenance, Out-Relief and the Establishment are divided between the Parishes according to their share of paupers and the amounts entered on the credit side of the Parochial Account against each Parish. "Supplemental Orders" for the collection of additional rates are recorded on parishes where the amount dispensed in poor relief exceeded their initial contribution. Parishes which contributed more than the expenditure on their behalf show the amount on the credit side of the Parochial Account as "By Balance with Treasurer". The net amount of over contribution equals the balancing figure on the Treasurers Account and is carried forward as a debit balance to the following quarter. This balance represents the amount of cash held in the Union bank account.

The specimen accounts are a cash-based single-entry bookkeeping system which focuses solely on accounting between the Union and the parishes. They do not demonstrate the DEB Chadwick required in the accompanying letter. The Schedule A records demonstrate that uniformity and standardisation of record keeping was not synonymous with DEB but, when it came to creating the Unions as wholly new administrative organisations there are good reasons for assuming that Chadwick wanted their Clerks to use DEB to symbolise their modernity and the break with the old, discredited parish system of administration. Chadwick was influenced by contemporary debates on accounting in government and by his connection with Bentham and with Bowring. He was familiar with Bentham's Pauper Management Improved (Bowring 1843) in which Bentham enthused on the advantages of forms and the tabulation of data for management purposes. In 
the chapter on Book-Keeping, Bentham was dismissive of the obfuscating terminology of DEB although his descriptions of cross-referencing "suggest that his system was less innocent of double-entry than he supposed" (Hume 1970, 28). In the Constitutional Code, Bentham advocated a centrally administered system of government finances (ibid and Gallhofer and Haslam 1994a) and there is some evidence that, towards the end of his life, he favoured a simplified system of DEB for the public accounts (Gallhofer and Haslam 1994b, 442). Chadwick became Bentham's secretary in 1831, specifically to help draft the Constitutional Code. He would have been aware of the proposals for the cash-based DEB favoured by the 1828 Parliamentary Commission and it would be surprising if he were not familiar with Bowring's 1831 reports on the public accounts in France. ${ }^{10}$ As noted above, in these reports Bowring championed the use of accruals-based DEB, receipts and payment accounts and balance sheets, as well as standardised forms to create a uniform system of local financial administration under central direction and control. Chadwick's intention under the new Poor Law was to institute a uniformity of administrative practice through the use of standardised forms and, in 1835, cash-based DEB for the Union accounts. Chadwick probably delegated the production of the specimen accounts. Nevertheless, the inclusion of a model of bookkeeping practice which used single-entry is incongruous in this context and suggests genuine confusion and a lack of knowledge and experience.

\section{The Amended Order of 1836}

Within a year the Commission had issued an Amended Order for Keeping and Auditing the Accounts of Unions (Poor Law Commissioners 1836a). In their Second Annual Report, the Poor Law Commissioners stated that the original Order had introduced a system superior to anything which had preceded it but that, as a result of implementation in newly formed Unions, "some improvements have been suggested in certain of the forms" (Poor Law Commissioners 1836b, 21). A complete list of the forms required under each Schedule is given by Walker (2008, Table 1). Several of the Schedule B forms were amended and the 1836 Order was much clearer on the reports each Union was required to send to the Poor Law Commission. In particular, the Union Clerk was instructed to send a copy of the audited Form 11 whereas the 1835 Order requested only Form 14. Much of the detail the Poor Law Commission wanted to include in its statistical reports was missing from Form 14, notably data on the paupers in each parish. The failure by the centre to ask specifically for the data it wanted in the 1835 
Order was corrected in 1836.

Although not specifically acknowledged, the most notable change made by the Amended Order was in the demonstration of the use of the minute book and the general ledger. The Amended Order stipulates that these are to be completed according to the example provided. The specimen is a Union with four parishes only but it is far more detailed and comprehensive in the range of accounts included than the 1835 specimen accounts. For example, the ledger includes an Exchequer Loan account to record the finance raised to build a new workhouse. The ledger accounts include personal accounts for the Relieving Officer and for a baker supplying bread for out-relief.

At the end of the quarter, the minute book demonstrates how the clerk should close the Establishment, In-maintenance and Out-relief accounts by debiting the Parish accounts with charges calculated for each parish. The Clerk is required then "to carry the several balances to the balance sheet, to prove the correctness of the ledger for the quarter" (Poor Law Commissioners, 1836a: p. 126). This wording echoes that used by Assistant Commissioner Adey writing to the Commission on 24th June 1835 with a suggestion to improve the Union accounts. The date of his letter suggests that he was commenting on a draft of the 1835 Order (20 June 1835, MH32/5). In his opinion, there was an omission from these Union accounts, as follows:

...there is no example to show that the several accounts in the Ledger are correct, which correctness is proved by a "Balance Account"....This "Balance Account" ought, but seldom does, form an account in the Ledger, and no Ledger can be called closed and proved correct without such an account - with Merchants it is generally in a Private Ledger with their Stock and Profit and Loss Accounts

(24 June 1835, MH32/5).

In the specimen accounts of the Amended Order, the balance sheet is shown as the last account in the ledger and is followed by a statement from the Auditor. ${ }^{11}$ The example shows liabilities to two tradesmen and the Exchequer Loan Commissioners and debit balances on the Parishes and Relieving Officers' accounts as debtors, the asset of the stock of provisions held by the workhouse and cash in the bank account (Treasurer). 
The specimen minute book and general ledger make it clear that a sophisticated accruals-based system of DEB was expected under the 1836 Amended Order. The system, with its audited quarterly balance sheet in the ledger, exemplified the uniformity of local administration under central direction and control that the new Poor Law sought to impose. It was modern and bureaucratic; the contrast with the charge and discharge accounts of parish officers administering the old Poor Law could not have been starker. What is surprising is that the first attempt to set out the detail of the new uniformity was delayed until September 1835 and, when it was issued, was so muddled and inconsistent that a significantly different Amended Order had to be issued a year later. There is some evidence from Chadwick's Explanatory Statement and from Assistant Commissioner Adey's letter that the 1835 specimen minute book and ledger was a mistake and that a genuine system of double-entry bookkeeping was intended from the outset. However, the fully developed model for the "uniform system of accounts" did not materialise until August 1836, two years after the new Poor Law had been passed.

\section{Implementation: achieving compliance}

The process of designing the rule-system for keeping the Union accounts was protracted and marked by trial and error. However, the implementation of the "correct and uniform system of accounts" is of greater significance in the history of government accounting than its design. This section assembles evidence from various archives to look at the extent to which local accounting records conformed to the norms established by the Orders. The archives give us an insight into the processes by which the new accounting was institutionalised and the role of individual Assistant Commissioners and of model accounts that could be copied and in achieving this. Also, this section considers the importance of authority and authorisation to act in a rules-based bureaucracy as well as sanctions to coerce compliance. The archives of correspondence between Assistant Poor Law Commissioners, like D. G. Adey, and Chadwick and the Poor Law Commissioners are considered first followed by the archives of individual Unions.

\section{Mimetic processes and change agents}


The Assistant Commissioners were key channels of communication between the Poor Law Commission and the localities and were instrumental in establishing the new Unions. They sometimes had an input into changes in the accounting requirements as well as commenting on how the accounting regulations were working in practice. The archive of correspondence is enormous, so searching for traces of the debates on the system of bookkeeping and financial reporting that must have been taking place in the period from 1834 to 1836 is daunting. Registers of correspondence from the Assistant Commissioners (MH33 series) are useful but the correspondence itself is sometimes incomplete for this early period (MH32 series). Twenty two Assistant Commissioners had been involved in the formation of 350 Unions in England and Wales, comprising up to 7,900 parishes, by the time the Amended Order was issued (Poor Law Commissioners 1836b, 4). Correspondence from Colonel à Court, Edward Gulson, Alfred Power, D. G. Adey, T. Stevens and W.H.T. Hawley have been searched to glean insights into how the Commission regulated Union bookkeeping in 1835 and 1836. Unfortunately, none of the correspondence seen discussed the 1836 Amended Order.

There were a number of requests from Assistant Commissioners for forms and guidance in the months before the 1835 Order was issued. For example, Alfred Power wrote to the Commissioners on 28 April 1835 asking to "do me the favour to inform me whether any forms are at present in readiness" (MH32/63). His request was repeated a few weeks later in a letter to Chadwick (ibid. 13th May 1835). Thomas Stevens ${ }^{12}$ wrote as the newly appointed vice-chairman of the Bradfield Union, Berkshire on 27 March 1835 asking for "instructions as to the mode of keeping the accounts" (MH33/5). A note is made in reply that the Commissioners "hope in a short time to be able to send the forms of accounts he wishes for" (ibid). The Assistant Commissioner in attendance at the first meeting of the Bradfield Union was Edward Gulson. Almost six months later, a relieved Gulson wrote to the Poor Law Commission secretariat on $15^{\text {th }}$ September, 1835, "I have this morning received the Forms of accounts etc. - for which I am obliged and I am desperately glad that they are out - Pray take care that they are posted directly to all my unions particularly those first formed - as they are getting terribly into arrear" (MH32/28). However, further delays followed in some areas because of problems with the publishers, resulting in the Commission's decision to organise an emergency despatch of ledgers and minute books from London by coach to Union clerks awaiting their first accounting books (letter from Chadwick dated $21^{\text {st }}$ September 1835, 
MH10/7).

Assistant Commissioner Adey acknowledged receipt of the 1835 Order on 15 September 1835 but stated that he had not had time to look at it (MH32/5). Unfortunately, there is nothing of substance in the register of his correspondence or in the volume of his letters that records his comments on the Order or its single-entry model accounts. ${ }^{13}$ Assistant Commissioner Alfred Power was very complimentary about the "excellent system of accounts recently issued by your Board" (29 October 1835, MH32/63). However, in a letter to Chadwick dated 10 November, he complained that the problem in some areas was that while the publisher was sending the forms, the union officers had not received copies of the Order:

A great deal of trouble is caused by the attempts to explain the use of the forms verbally, which afterwards frequently appeared to have been thrown away. I trust that yourself and the Board are aware that the omission to send these Orders of Accounts produces almost an entire stoppage in the proceedings of the new Unions; which cannot proceed to the administration of relief without the authorised instructions for keeping the accounts

(MH32/63).

The first comment could suggest that some Union clerks were less than enthusiastic about their bookkeeping and form-filling duties. However, the final comment indicates that where Unions had been established, they were unwilling to perform their role in administering poor relief without receipt of the written Order and the specimen model accounts; they were not prepared to act on the spoken word of the Assistant Commissioners. The coercive pressure on Unions to implement the required bookkeeping system was embedded in the statutory authority exercised by the Poor Law Commission. In the early days, Union officers and/or Boards of Guardians, may have been wary of proceeding with a radically new system until they had received irrefutable authorisation and instruction in written form. Furthermore, it implies that the Unions, as creations of the 1834 Act, saw the discharge of their responsibilities and the recording system they were expected to use as intrinsically bound together. Thus, the accounting was a significant means by which the new Poor Law administration was constituted.

\section{Bookkeeping and accounting in the unions}


Union records were analysed to investigate the match between how things should have been recorded, and how they were actually recorded. A sample was drawn from Unions formed in the first years of reform. These were in rural areas of southern England where the local gentry and the ratepayers were generally keen to make the 1834 Poor Law Amendment Act work because of its scope for reducing rates, improving administrative efficiency and disciplining the able-bodied poor (Brundage 2002). Therefore, we might expect to find a high degree of conformity in the record keeping by these Unions.

The evidence for Union bookkeeping practices comprises the minute book and the ledger. Survival rates for minute books are high but there are far fewer ledgers from the early period. Analysing the index of Poor Law Union records produced by Gibson and Rogers (2000) for ten counties in southern England revealed that the minute books are available for 93 Unions established in 1835 or $1836 .{ }^{14}$ However, ledgers survive for only 9 Unions dating from 1835 and for 16 dating from 1836. Three-quarters of these are for Unions in Gloucestershire (6) and Somerset (12). The comments which follow are based on the minute books and ledgers of the Poor Law Unions listed in Table 1 (all the records examined are listed below, under primary sources). The Unions were selected subjectively but are thought to give a reasonable indication of the range of recording practices under the 1835 Order and the 1836 Amended Order.

\section{Table 1: Summary of the union archives examined}

\begin{tabular}{|l|l|l|c|c|c|}
\hline County & \multicolumn{1}{|c|}{ Union } & \multicolumn{1}{|c|}{$\begin{array}{c}\text { Date of first } \\
\text { meeting }\end{array}$} & $\begin{array}{c}\text { Parishes } \\
\text { United }\end{array}$ & $\begin{array}{c}\text { First Assistant } \\
\text { Poor Law } \\
\text { Commissioner }\end{array}$ & Ledger \\
\hline Berkshire & Abingdon ${ }^{15}$ & $7^{\text {th }}$ Oct. 1835 & 38 & & No \\
\cline { 2 - 4 } & Bradfield & $12^{\text {th }}$ Mar. 1835 & 29 & \multirow{2}{*}{ Edward Gulson } & No \\
\cline { 2 - 4 } & Farringdon & $7^{\text {th }}$ Feb. 1835 & 31 & & No \\
\hline Oxfordshire & Bicester & $4^{\text {th }}$ Aug. 1835 & 38 & Richard Hall & No \\
\cline { 2 - 3 } & Henley & $21^{\text {st }}$ July 1835 & 21 & \multirow{2}{*}{ Edward Gulson } & No \\
\cline { 2 - 3 } & Thame & $18^{\text {th }}$ Sept. 1835 & 34 & & No \\
\hline
\end{tabular}




\begin{tabular}{|c|c|c|c|c|c|}
\hline \multirow[t]{3}{*}{ Gloucs. } & Tetbury & $2^{\text {nd }}$ Apr. 1836 & 13 & \multirow{3}{*}{ Robert Weale } & Yes \\
\hline & $\begin{array}{l}\text { Westbury-on- } \\
\text { Severn }\end{array}$ & $29^{\text {th }}$ Sept. 1835 & 13 & & Yes \\
\hline & \begin{tabular}{|l|} 
Wheatenhurst \\
\end{tabular} & $23^{\text {rd }}$ Sept. 1835 & 14 & & Yes \\
\hline \multirow[t]{3}{*}{ Somerset } & Dulverton & $19^{\text {th }}$ May 1836 & 11 & \multirow{3}{*}{ Robert Weale } & Yes \\
\hline & Frome & $28^{\text {th }}$ Mar. 1836 & 28 & & Yes \\
\hline & \begin{tabular}{|l|} 
Wincanton \\
\end{tabular} & $31^{\text {st }}$ Dec. 1835 & 39 & & Yes \\
\hline
\end{tabular}

Two of these Unions, Farringdon and Bradfield, had been in existence seven to eight months before the 1835 Order was issued. It is clear that the Board of Guardians assumed responsibility for checking and agreeing the relief given to paupers but that this continued to be administered by individual parish overseers until September 1835. Farringdon's Relieving Officers took up their posts at the start of the September to December quarter, 1835. The evidence from the minute book clearly indicates that the Order was being followed and includes folio references to the ledger $(\mathrm{G} / \mathrm{F} / 1 / 1)$. Like Farringdon, the early meetings of the Bradfield Board of Guardians vetted the applications for relief, and checked and approved the expenditure by individual parish overseers who continued to administer poor relief. As noted above, Thomas Stevens wrote to the Commission in March asking for "instructions as to the mode of keeping the accounts" (MH33/5). Concern about keeping proper accounts continued. On July $20^{\text {th }} 1835$, the minute book reproduces a letter from the Union auditor which ends with the following:

I think the Board should order immediately, a set of Books for the Clerk, and that they should be kept by the principle of double entry as suggested by the Poor Law Commissioners but I think there is no necessity of a Day Book, the Minute book if properly kept, answering every purpose. I think the Accounts in the Books should begin from the commencement of the Union. A Journal and Ledger will be all that will be required.

(G/B 1/1)

This implies that a draft Order had been circulated, perhaps to a limited Page $\mid 21$ 
number of people, in the summer of 1835 . However, there are no changes to the way in which the Bradfield Union minute book is kept until the first meeting of the September to December quarter, 1835. This notes:

The Relieving Officers Books were examined and found correct, and it appearing thereby that the Relieving Officers had paid the following sums to paupers, as Out Relief, under the orders of the Board of Guardians the account of Out Relief Charges in the Ledger against the Parishes to which the paupers severally belong were directed to be debited therewith

(5th October 1835, G/B/1/1).

The wording is exactly as in the specimen minute book, folio 2 of the 1835 Order although the Bradfield minutes omit references to the ledger folios. The Bradfield minute book continues to detail individual cases but all financial references indicate that the 1835 Order was followed carefully from the September to December quarter, 1835.

Bicester and Henley Unions were formed in the summer of 1835. Henley appointed Relieving Officers in early July and they were distributing relief by the end of that month (PLU4/G/1A1/1). Bicester appointed its Relieving Officers in mid-August but they probably did not start distributing relief until a month later. The minute book records the first payment of cheques to each "for his current expenses" on $11^{\text {th }}$ September and in the week following, records that "the accounts of the relieving officer of the (Hethe) District were examined found correct and passed" (PLU2/G/1A1/1). This wording is as given in the specimen minute book but there is no reference to any accounting entries in a ledger. Thereafter, the clerk of the Bicester Union continued to use the phrases in the specimen minute book, indicating that the single-entry bookkeeping system illustrated by the specimen accounts was being used although he rarely indicated the folio of the ledger accounts.

Until a new Board had appointed its Relieving Officers, the parish overseers continued to distribute relief, albeit under Union supervision. This interim period was especially protracted in the cases of Farringdon and Bradfield and it seems that they waited until the new Order had been issued to provide authorisation for the change. This response corroborates the implication of Alfred Powell's comments noted above, in relation to some of his Unions namely, that the legal authority of the Order was a significant factor in 
determining what the Unions did as well as how they recorded their administration of the 1834 Act. In this sense, the Order for Keeping Accounts was constitutive of the new administration. However, other Unions, such as Bicester and Henley, were less cautious and assumed their responsibilities for the distribution of poor relief in the weeks before the Order was issued. Although no ledgers survive for these early Unions, all the minute books examined showed that, from the September to December 1835 quarter, they were copying the specimen accounts which accompanied the 1835 Order.

The 1835 Order had been issued by the time that the Thame Union and the enlarged Abingdon Union had been formed. Both Unions followed the specimen minute book closely, copying the form of words used and giving folio references to the ledger $(\mathrm{G} / \mathrm{A} / 1 / 1$ and PLU5/G/1A1). The Unions in Somerset and Gloucestershire listed above, were all formed after the date of the 1835 Order and before the Amended Order was published but for these Unions, the ledgers as well as the minute books have survived. All used a bound and pre-printed general accounting ledger but not one especially designed for Poor Law Unions. The ledgers for Tetbury, Westbury-onSevern, Wheatenhurst, Wincanton and Frome show the bookkeeping illustrated by the specimen ledger (G\TET 9a/1; G\WE 9a/1A; GIWH 9a/1;

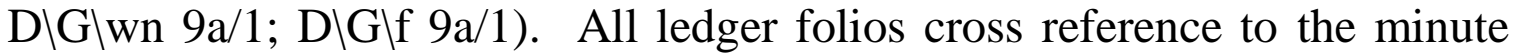
book and the minute books generally adopt the form of words used in the

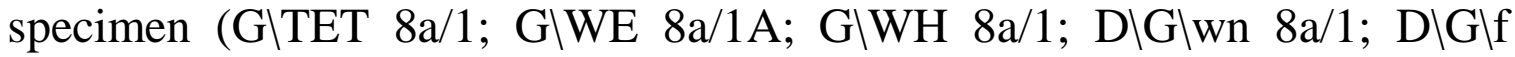
$8 \mathrm{a} / 1)$. Only one Union, Dulverton, ignored the 1835 Order although it should have produced the accounts for one quarter under its direction (June to September 1836). Instead, the ledger for this quarter devotes one doublepage to each parish. The debit side of each account shows the amount paid in poor relief each week and an apportionment of Establishment expenses while on the credit side of the account, the amount shown is described as "as allowed by rate" (D\Gld 9a/1). There are no other accounts and no folio references to the minute book. Similarly, the style in which the minute book is kept is very different from those basing their recording on the specimen minute book. The Dulverton minute book is a record of the debates and resolutions at its Board meetings not a journal in its bookkeeping system (D\Gld 8a/1).

The evidence suggests that, on the whole, the Unions followed the singleentry specimen accounts attached to the 1835 Order. There was no evidence to suggest that the early Unions voluntarily chose to use accruals-based DEB 
although this was permitted by the 1835 Order. However, when the Unions were required to change their recording system to the accruals-based DEB stipulated by the Amended Order of 1836, most did so. Dulverton and Wheatenhurst did not. The Farringdon minute book records that "the clerk was directed to order the necessary Books prescribed by the new Order of the Poor Law Commissioners for the use of the Union and the parishes within the Union from Mr. Knight the publisher" (30 ${ }^{\text {th }}$ August G/F 1/2). These official minute books and ledgers included a copy of the Amended Order specimen minute book and Ledger accounts respectively. Most of the Somerset and Gloucester Unions continued to use their existing stationery but adapted their ledgers for the quarter ending December 1836 to accommodate the new double-entry recording system by adding columns and hand written headings to show the ledger folio reference for the corresponding double-entry. The first page of the Wincanton ledger announces the following:

Wincanton Union Ledger 1836. Robert Clarke, Clerk. Commencing at the formation of the Union on the $31^{\text {st }}$ December 1835 and ending on the $28^{\text {th }}$ September 1836 when the amended form of Accounts and new Ledger were adopted pursuant to an order of the Poor Law Commissioners dated $10^{\text {th }}$ Aug 1836.

(D)Glwn 9a/1)

This statement points again to the importance of the statutory authority of the Poor Law Commission in determining how the Union administrative systems should operate and the careful compliance by early Unions such as Wincanton, with those instructions.

However, compliance with the change to accruals-based DEB was not universal. Wheatenhurst did not amend its ledger until two years later, maintaining the system of recording under the 1835 Order until that time. Dulverton appears to have used the ledger for different purposes at different times. Eventually, in the quarter ending December 1838, there is some double-entry recording of cash transactions with the Treasurers account and a Balances account appears for the first time. However, there is no Outrelief account until Dulverton started a new ledger in the quarter ending September 1839 when the full system of recording required by the Amended Order is followed (D $\mid$ Gld 9a/2). The new ledger includes a copy of the specimen ledger accounts produced with the Amended Order. However, the entries in the minute book do not reflect the Order and do not give any 
references to folios in the ledger. Had the ledger not survived, it would be reasonable but incorrect to infer from the minute book that Dulverton did not keep its accounts in the required manner for any of this period. Perhaps the records from Dulverton failed to conform not because the Clerk was recalcitrant but because he did not have a copy of the specimen accounts. The close copying of the specimen accounts by other Union clerks indicates their importance as instructional tools as well as being a key means by which the Commission sought to achieve uniformity.

In general, it does appear to be the case that Unions following the Amended Order in their ledger accounts, also adopted the wording of the specimen minute book entries, and usually included the ledger folio references in the minute book margins. Thus, it can be inferred that the Oxfordshire and Berkshire Unions switched to the recording system of the Amended Oder as soon as this was required (from the end of September 1836). The first descriptions of accounting entries in the minute books of both Thame and Bicester under the new regime indicate an initial lack of familiarity with the double-entry system. At Thame, the payment of cheques to the Relieving Officers was initially entered with the phrase "the Out Relief Account to be credited therewith" as under the 1835 Order but this is crossed through and the phrase "their respective Accounts to be debited and the Treasurer credited with the same" added, copying the wording for similar entries in the specimen minute book for the Amended Order and showing the ledger folio references in the margin ( $28^{\text {th }}$ September 1836, PLU5/G/1A1). At Bicester, the first entry for the amounts paid out in poor relief by the Relieving Officers under the Amended Order, initially records that their accounts were ordered to be debited with the amounts ( $19^{\text {th }}$ October, PLU2/G/1A1). The "debited" is crossed through and "credited" is substituted. No ledger folio references are given and there is no mention of the corresponding debit in the Out-relief account. Otherwise, the wording copies the form of words used in the specimen minute book.

An important feature of the ledger accounts under the Amended Order was the requirement to produce a Balance Account or Balance Sheet at the end of each quarter "to prove the correctness of the ledger for that quarter" (Poor Law Commissioners 1836a, specimen minute book, folio 6). The Balance Sheets and the auditor's statements, worded as in the specimen ledger, are routinely included in the ledgers examined. However, the Dulverton ledger includes statements from the auditor which do not follow the form of words required by the Amended Order. There are also several quarters with no 
audit statement and the occasional annotation in the ledger which perhaps indicate some frustration with the idiosyncratic approach taken by the Dulverton clerk. When Dulverton produced a Balance Sheet for the first time (quarter ending December 1838) the auditor added a note which states "A similar Balance Sheet is to be prepared every quarter previous to the audit and it must be signed by the auditor before the salary of any officer can be paid by the Board of Guardians" (D\Gld 9a/1).

The withholding of salaries pending the audit of an officer's records was stipulated in the Amended Order. However, from the records examined, there was no clear evidence that in practice, salary payments were delayed until after the audit. The minute books and ledgers tend to show the cheques for salaries paid entered and/or recorded at the date of the last Board meeting of the quarter, with the audit occurring some weeks later. This suggests some tension between the concern to compel officers to keep "correct" accounts and the desire to close cash accounts as soon as possible. The accruals accounting illustrated elsewhere in the Amended Order could have been used to create personal creditor accounts for officers owed salary payments. Instead, the specimen minute book and ledger produce a fudge. They show salaries being paid on the date of the last meeting of the financial quarter but with a footnote stating that:

Practically the salaries of the officers...cannot be charged in the accounts of the current quarter, as they cannot be allowed or paid until after each audit ... This minute is inserted here as an exemplification only of the manner in which the fact should be recorded.

(Poor Law Commissioners, 1836a: p. 124)

The only indication that the coercive device of withholding salaries until the successful completion of the audit was being exercised came from one entry in the minute book for the Frome Union. This records that the "Auditor having reported that he had audited and allowed the accounts of the several officers of the Union. Ordered that checks for the salaries of those officers for the quarter ending $27^{\text {th }}$ September last be signed" ( $4^{\text {th }}$ October 1836 , $\mathrm{D} \backslash \mathrm{G} \backslash \mathrm{f} 8 \mathrm{a} / 1)$. The ledger shows the salary checks credited in the Treasurers account and debited to Establishment on $27^{\text {th }}$ September. So, perhaps Union officers were disciplined to keep proper records by the withholding of their salaries in this devious manner. Such a conclusion seems unlikely as this particular minute book entry appears unique. Also, the auditor's reproof of 
the clerk of the Dulverton Union may have used a reminder of the statutory authority of the Order on this matter as a means of exhorting him to produce full and "correct" records in future when he had so conspicuously failed to do so in the past (without forfeiting his salary).

\section{Conclusions}

The new Poor Law of 1834 was intended to transform the administration of poor relief. However, from a Weberian perspective, the new administrative machinery mixed elements of the feudal and the modern. At the level of the churchwardens and overseers, the transformation meant the removal of their responsibility to distribute poor relief, leaving the main financial duty of parish officers as the collection of the poor rates and the remittance of those rates to the Union Treasurer. However, the old feudal structures at the parish level were not replaced entirely by the new authority vested in the Poor Law Commission. The parish officers continued to perform their year of office on the old basis of voluntary service and they were required to keep cash-based, single entry records. Charge and discharge accounting lived on. However, they came under the authority of the central, London-based Poor Law Commission which sought to impose uniformity on the records they kept by designing and disseminating a set of standardised forms.

The radically new organisations at the local level were the Unions of parishes. Centralising reformers like Edwin Chadwick, wanted all Unions to conform to a model of order, uniformity and efficiency. The mechanisms used by him, and the Poor Law Commissioners, to try to achieve this included the guiding and advisory role of the Assistant Commissioners, the creation of a salaried bureaucracy of Union clerks, Relieving Officers, workhouse staff and auditors, and the design of the pre-printed forms these local officials were required to complete. For the clerk of each Union, those forms included a minute book (journal) and a general ledger kept by doubleentry. Chadwick regarded DEB as the basis of a "correct" system of accounts. The financial accounting required under the new Poor Law brought together DEB and financial reporting by means of a "receipts and expenditure" account and balance sheet, thereby marking a distinct break with feudal charge and discharge accounting. The modern bureaucratic accounting intended for the hundreds of Poor Law Unions in England and Wales is in marked contrast to the patchy adoption of DEB in central government departments and the lack of central intervention in the accounting regulation of the municipal corporations of the 1830 s. The new 
Poor Law accounting is a remarkable landmark in the history of government accounting that has hitherto attracted insufficient attention by historians.

The bookkeeping rule-based system specified towards the end of 1836 was a signature of the modern, bureaucratic form of organisation. However, the design of this accounting technology resulted in a faltering gestation. The Commission's first attempt to describe exactly how the new bookkeeping and financial reporting system should work did not appear until a year after the Act. The 1835 Order described a cash-based DEB system, permitted an accruals-based DEB system and was illustrated by a single-entry system restricted to an unrealistically limited set of transactions. The logically inconsistent 1835 Order was replaced a year later by the 1836 Amended Order which defined the bookkeeping system for the decades that followed.

An examination of the archives indicates that the delays affected not only the record keeping but also the manner of poor relief distribution which continued, in some Union areas, as it had done in pre-Union days until the 1835 Order had been received. Surprisingly, the 1835 Order and its contrary, single-entry specimen accounts do not seem to have created confusion or consternation in the Unions. The archives examined show that, in general, the Union clerks simply mimicked the model records. Likewise, the sudden change required by the 1836 Amended Order appears to have elicited an immediate and generally smooth switch to accruals-based DEB. The main exception was the idiosyncratic recording practices of the Union clerk in Dulverton.

This paper has argued that the Assistant Poor Law Commissioners and the model accounts produced by the Commission were the essential change agents in the process of disseminating the new accounting and embedding these practices in the localities. Furthermore, it appears that respect for the statutory authority of the Orders issued by the Poor Law Commission was a prerequisite for achieving the remarkable level of uniformity and compliance observed. For most of these early Unions, it seems that the written authority of the Poor Law Commission was unquestioned and the specimen accounts provided by the Commission were copied with meticulous care, even when they were incorrect. Poor Law history in general, is one of both compliance and resistance to central authority (Brundage 2002). This picture of bureaucratic, centrally imposed uniformity in the accounting records may not be evident in areas of England and Wales which resisted the 1834 Poor Law. Further archival research would provide interesting evidence on Page $\mid 28$ 
bookkeeping and accounting in areas where the Commission found it most difficult to impose its rule.

\section{Acknowledgements}

This paper could not have been completed without the patience and encouragement of the Editors of Accounting, Business \& Financial History and Accounting History Review. Anonymous referees have given constructive comments and the author is particularly grateful to Stephen P. Walker for his helpful insights, observations and suggestions to improve the paper.

\section{References}

\section{Primary Sources}

Parliamentary Papers

Bowring, J. 1831. Reports on public accounts of France, House of Commons Parliamentary Papers 14: 1-353.

Poor Law Board .1867a. Circular letter accompanying the general order for accounts, appendix no. 12 to the nineteenth annual report of the poor law board, House of Commons Parliamentary Papers 34: 125-6.

Poor Law Board. 1867b. General order for regulating the keeping, examining, closing, and auditing of union and parochial accounts. Appendix no. 11 to the nineteenth annual report of the poor law board. House of Commons Parliamentary Papers 34: $51-125$.

Poor Law Commissioners. 1835. Order for keeping, examining and auditing of accounts. Appendix to the first annual report of the poor law commissioners for England and Wales. House of Commons Parliamentary Papers 35: 66-103.

Poor Law Commissioners. 1836a. Amended order for keeping and auditing the accounts of unions. Appendix a no. 13. Second annual report of the poor law commissioners of England and Wales. House of Commons Parliamentary Papers 29, no. 1: 95139.

Poor Law Commissioners.1836b. Second annual report of the poor law commissioners of England and Wales. House of Commons Parliamentary Papers 29, no. 1: 1-35.

National Archives, Kew, London:

MH10 Ministry of Health and predecessors: Circular Letters.

MH10/7 from the PLC to Union and Parish Officers, 1834-1837

MH32 Assistant Poor Law Commissioners

MH32/5 Mr. D.G. Adey

MH32/28 Mr. Edward Gulson

MH32/63 Mr. A. Power

MH33/1 Register of correspondence

Page $\mid 29$ 
MH33/5 Register of correspondence

Berkshire Record Office, Reading:

G/A/1/1 Abingdon PLU minute book (1835-1836)

G/B/1/1 Bradfield PLU minute book (1835-1836)

G/F/1/1 Faringdon PLU minute book (1835-1836)

Gloucestershire Record Office, Gloucester:

GITET 8a/1 Tetbury PLU minute book (1836-1844)

GITET 9a/1 Tetbury PLU general ledger (1836-1839)

GIWE 8a/1 Westbury on Severn PLU minute book (1835-1837)

GIWE 9a/1A Westbury on Severn PLU general ledger (1835-1837)

GIWH 8a/1 Wheatenhurst PLU minute book (1835-1838)

GIWH 9a/1 Wheatenhurst PLU general ledger (1835-1838)

Oxfordshire Record Office, Oxford:

PLU2/G/1A1/ Bicester PLU minute books (from 1835, on microfilm)

PLU4/G/1A1/ Henley PLU minute book (from 1835, on microfilm)

PLU5/G/1A1/ Thame PLU minute book (from 1835, on microfilm)

Somerset Record Office, Taunton:

DIGld 8a/1 Dulverton PLU minute book (1836-1842)

D\G\d 9a/1 Dulverton PLU general ledger (1836-1839)

DIGld 9a/2 Dulverton PLU general ledger (1839-1842)

DIGIf 8a/1 Frome PLU minute book (Mar 1836 - Dec 1836)

DIGlf 9a/1 Frome PLU general ledger (1836)

D\Glwn 8a/1 Wincanton PLU minute book (1835-1837)

D\Glwn 9a/1 Wincanton PLU general ledger (1835-1840)

\section{Secondary sources}

Anstruther, I. 1973. The scandal of the Andover workhouse. Tiptree: Anchor Press.

Bowring, J. 1843. The works of Jeremy Bentham, volume VIII. Edinburgh: William Tait). Brundage, A. 1988. England's "Prussian minister": Edwin Chadwick and the politics of government growth, 1832-1854. University Park: The Pennsylvania State University Press.

Brundage, A. 1990. Debate. The making of the new poor law redivivus. Past and Present 127, no. 1: 183-86.

Brundage, A. 2002. The English poor laws, 1700-1930. Basingstoke: Palgrave.

Bryer, R. A. 1998. The struggle to maturity in writing the history of accounting, and the promise - some reflections on Keenan's defence of "Traditional" Methodology". Critical Perspectives on Accounting 9, no. 6: 669-81.

Bryer, R. A. 2000a. The history of accounting and the transition to capitalism in England. Part one: Theory. Accounting, Organizations and Society 25, no. 2: 131-62.

Bryer, R. A. 2000b. The history of accounting and the transition to capitalism in England.

Page $\mid 30$ 
Part two: Evidence, Accounting, Organizations and Society 25, no. 4-5: 327-81.

Chiapello, E. 2007. Accounting and the birth of the notion of capitalism. Critical Perspectives on Accounting 18, no. 3: 263-96.

Colquhoun, P. 2009. The state. In The Routledge companion to accounting history, eds. J.R. Edwards and S.P. Walker, 543-60. Abingdon: Routledge.

Coombs, H. M. and J.R. Edwards. (1990). The evolution of the district audit, Financial Accountability and Management 6, no. 3: 153-76.

Coombs, H. M. and J.R. Edwards. (1994). Record keeping in municipal corporations: A triumph for double entry bookkeeping. Accounting, Business \& Financial History 4, no. 1: 163-80.

Digby, A. 1982. The poor law in nineteenth-century England and Wales. London: Historical Association).

Dunkley, P. 1981. Whigs and paupers: The reform of the English poor laws, 1830-1834. The Journal of British Studies 20, no. 2: 124-49.

Eastwood, D. 1990. Debate. The making of the new poor law redivivus. Past and Present 127, no. 1: 186-27.

Eastwood, D. 1997. Government and community in the English provinces, 1700-1870. Basingstoke: Macmillan ).

Edwards, J. R., H.M. Coombs and H.T. Greener. 2002. British central government and "The mercantile system of double entry" bookkeeping: A study of ideological conflict. Accounting, Organizations and Society 27, no. 7: 637-58.

Edwards, J. R. and H.T. Greener. 2003. Introducing 'mercantile' bookkeeping into British central government, 1828-1844. Accounting and Business Research 33, no. 1: 5164.

Englander, D. 1998. Poverty and poor law reform in Britain: From Chadwick to Booth, 1934 -1914. London: Longman.

Finer, S. E. 1970. The life and times of Sir Edwin Chadwick. New York: Barnes and Noble Inc.

Gallhofer, S. and J. Haslam. 1994a. Accounting and the Benthams - or accounting's potentialities, Accounting, Business \& Financial History 4, no. 3: 431-60.

Gallhofer, S. and J. Haslam. 1994b. Accounting and the Benthams: Accounting as negation? Accounting, Business \& Financial History 4, no. 2: 239-73.

Gibson, J. and C. Rogers. 2000. Poor Law Union Records: 3. South-west England, the Marches and Wales. Bury: Federation of Family History Societies.

Hume, L. J. 1970. The development of industrial accounting: the Benthams' contribution. Journal of Accounting Research 8: 21-33.

Jones, R. H. 1985. Accounting in English local government from the middle ages to c.1835. Accounting and Business Research 15, no. 59: 197-209.

Jones, M. J. 2008. The role of change agents and imitation in the diffusion of an idea: charge and discharge accounting. Accounting and Business Research 38, no. 5: 355-71.

Jones, M. J. 2010. Sources of power and infrastructural conditions in medieval governmental accounting. Accounting, Organizations and Society 35, no. 1: 8194.

Keenan, M. G. 1998a. A defence of 'traditional' accounting history research methodology. Critical Perspectives on Accounting 9, no. 6: 641-66. 
Keenan, M. G. 1998b. Rhetoric, obfuscation and genealogies of calculation: A reply to my critics. Critical Perspectives on Accounting 9, no. 6: 713-19.

Lemarchand, Y. 1999. Introducing double-entry bookkeeping in public finance: A French experiment at the beginning of the eighteenth century. Accounting, Business \& Financial History 9, no. 2: 225-54.

Livock, D. M. 1984. The accounts of the corporation of Bristol: 1532 to 1835. In The development of double entry. Selected essays, ed. C. Nobes, 92-108. London: Garland Publishing.

Mandler, P. 1990. Reply. Past and Present 127, no. 1: 194-201.

Napier, C. J. 1991. Aristocratic accounting: The Bute estate in Glamorgan 1814-1880. Accounting and Business Research 21, no. 82: 163-74.

Napier, C. J. 1998. Giving an account of accounting history: A reply to Keenan. Critical Perspectives on Accounting 9, no. 6: 685-700.

Parker, R.H. 1993. Bowring and financial reform: Government accountancy and decimalisation. In Sir John Bowring (Aspects of his life and career), ed. J. Youings, 71-85. Plymouth: Devonshire Association.

Perrin, J. 1998. From cash to accruals in 25 years. Public Money and Management 18, no. 2: $7-10$.

Snell, K.D.M. 2006. Parish and belonging: community, identity and welfare in England and Wales, 1700-1950. Cambridge: Cambridge University Press.

Walker, S. P. 2004. Expense, social and moral control. Accounting and the administration of the old poor law in England and Wales. Journal of Accounting and Public Policy 23, no. 2: 85-127.

Walker, S. P. 2008. Accounting, paper shadows and the stigmatised poor. Accounting, Organizations and Society 33, no. 4-5: 453-87.

Webb, S. and B. Webb. 1952. English poor law history part ii: The last hundred years. Vol. 1. London: Frank Cass and Co.

Weber, M. 1991. From Max Weber: Essays in sociology, translated, edited with an introduction by H.H. Gerth and C. Wright Mills; with a new introduction by Bryan S. Turner. London: Routledge.

Williams, K. 1981. From pauperism to poverty. London: Routledge and Kegan Paul. Yamey, B. S. 2005. The historical significance of double-entry bookkeeping: some nonSombartian claims, Accounting, Business \& Financial History. 15, no. 1: 77-88.

\footnotetext{
${ }^{1}$ Although, the use of the terms "debit" and "credit" on the left and the right side respectively of a bilateral account may not be evidence for the use of DEB (for example, Edwards and Greener 2003).

${ }^{2}$ As well as the debate between Keenan, Napier and Bryer in the pages of Critical Perspectives on Accounting, debates around the history of DEB have been revisited and summarized by Chiapello (2007).

${ }^{3}$ A different explanation for the lack of central direction of the accounting required under the 1835 Municipal Corporations Act has been suggested by Coombs and Edwards (1994). They speculate that reform fatigue may have been a factor and that "it is unlikely that the government needed to be discouraged from introducing a DEB requirement but, if it did, there was an influential opponent in the persons of Jeremy Bentham and his disciple Edwin Chadwick" (ibid. 170). Subsequent research suggests that Bentham's opposition to DEB was not entrenched. Furthermore, as this paper argues, Chadwick became a champion of DEB. The ideological argument advanced here is more persuasive.

${ }^{4}$ The continuing power of the "commercial brand" can be discerned in a personal review of changes in government accounting at the end of the twentieth century by a leading academic adviser who equates full
}

Page $\mid 32$ 
accruals accounting with sophistication and is embarrassed by how "almost primitive the public sector accounting arrangements" were until the late twentieth century (Perrin 1998).

${ }^{5}$ It has been suggested that Chadwick would have liked to abolish local administration altogether in favour of a fully centralised service but decided it would be too expensive (Finer 1970). However, Brundage (1988) produces convincing evidence that this was Nassau Senior's idea although it may well have been opposed on cost grounds by Chadwick.

${ }^{6}$ The Commissioner's salary in 1834 was $£ 2,000$ per annum. The appointments were Shaw Lefevre, a Whig, and a friend and former bailiff of Lord Althorp; Thomas Frankland Lewis, a Tory country gentleman; and, George Nicholls a man well-known for his workhouse regime at Southwell, Nottinghamshire. Lefevre's and Lewis' appointments could be seen as patronage. Chadwick was persuaded to take the job of secretary on $£ 1,200$ a year.

${ }^{7}$ Jones $(1985,208)$ argues that it was not until 1867 that "parishes were for the first time uniformly required to adopt a double-entry system". This was not the case. The removal of the Settlement Laws allowed Poor Law records to be simplified and the Poor Law Board took the opportunity to introduce a number of amendments to the forms in the various Schedules at that time (Poor Law Board 1867a and 1867b). However, the changes made to the parish records kept by churchwardens and overseers were minor and did not introduce DEB.

${ }^{8}$ By 1834 there were 67 Gilbert Act Unions formed voluntarily by groups of parishes, mainly in rural areas in the East, South-east and Midlands. These were not subject to central government control before or after the 1834 Act. The Poor Law Commission had no authority over them and they were strongly opposed to any challenge to their local autonomy. Brundage describes them as expressions of the authority of local magistrates and country gentlemen landowners in their localities (2002, 21 and 72).

${ }^{9}$ In the early years of the new regime, the "paupers vanished as if by magic and the poor-rate fell by $20 \%$ " and although the change resulted from many factors, the Poor Law Commission claimed the credit (Anstruther 1973, 20). A full analysis of the statistics on poor law relief expenditure has been presented by Williams (1981) and has been re-examined recently by Snell (2006). Snell argues that the new law came at the end of a period of declining expenditure per head of population resulting from lessening pressure on resources after the Napoleonic Wars and from the growing economy. He concludes that the "claims made for the contribution of the New Poor Law in cutting expenditure were overplayed by its advocates" (ibid. 215).

${ }^{10}$ Chadwick and Bowring were both acquainted with and influenced by the parliamentarian radical Joseph Hume as well as sharing a close connection with Jeremy Bentham. Also, towards the end of the $1820 \mathrm{~s}$, Chadwick had published articles in the Westminster Review, edited by Bowring. Chadwick took over from Bowring as Bentham's secretary in 1831, living for a time in Bentham's house, while Bowring investigated the public accounts in France and the Netherlands in his new role as secretary to the 1831 Commission on Public Accounts. After Bentham's death in 1832, Bowring became Bentham's literary executor and the editor of his collected works.

${ }^{11}$ The wording of the auditor's statement is as follows: "I have examined the several accounts of which this is the balance sheet, and the several subsidiary accounts applicable to them, and I have compared the several debits with the vouchers and the corresponding credits ... and I do hereby certify that the entries appear to be correct and legal...(Poor Law Commissioners 1836b, 138).

${ }^{12}$ Thomas Stevens, a Berkshire squire, was a respondent to the 1832 Royal Commission and in January 1836 became an Assistant Commissioner.

${ }^{13}$ A note appears in response to one of his letters dated $28^{\text {th }}$ October 1835 stating that the Commissioners "are willing he should make a trial of his forms in the Unions where complaints of the forms recommended are made" (MH33/1). It is not clear if this refers to the forms kept by the Union Clerk, the Relieving Officers, the Master of the Workhouse or the parish officers. The trial may have had no implications for the Union ledger accounts.

${ }^{14}$ The ten counties are Berkshire, Oxfordshire, Devon, Dorset, Gloucestershire, Hampshire, Somerset, Wiltshire, Worcestershire and Herefordshire.

${ }^{15}$ Abingdon was the first Union formed under the 1834 Act, on $1^{\text {st }}$ January 1835 . Initially, it consisted of 14 parishes but was enlarged to 38 on $7^{\text {th }}$ October 1835 . The earliest surviving minutes relate to the enlarged Union. 
Page | 34 